\title{
Educational Programmes Related to Mineral Processing in Poland
}

\author{
Daniel SARAMAK ${ }^{1}$
}

\footnotetext{
1) AGH University of Science and Technology, Faculty of Mining and Geoengineering, Kraków, Poland; email: dsaramak@agh.edu.pl
}

http://doi.org/10.29227/IM-2020-01-75

Submission date: 16-12-2019 | Review date: 09-01-2020

\begin{abstract}
Mining and mineral processing is a significant field of research in Poland, mainly due to huge deposits of various raw materials located in this country. Several Polish universities offer studies in the field of mineral processing. AGH University of Science and Technology, located in Cracow is major Polish university offering MSc programmes in mineral processing discipline. There are also several other universities, where students can gain knowledge in the field of mineral processing. Teaching programmes cover all main issues related to mineral processing, with cooperation with coal, copper, zinc and lead, coal and rock material industries. Article also describes the issues related to scientific staff in Poland. There are also presented general possibilities for career development for graduates, with characteristics of main potentials and problems.
\end{abstract}

Keywords: mineral processing, higher education, AGH

\section{Introduction}

Several universities in Poland offer higher education in the field of mining and mineral processing. Graduates of two universities can gain diplomas of mineral processing engineer, and curricula in these universities offer comprehensive education in the field of raw materials processing and beneficiation technology, including waste management issues, as well as economic aspects. One of these universities is Silesian University of Technology, located in Gliwice, but the primary mineral processing university appears AGH University of Science and Technology (AGH UST) in Cracow. This university has one-hundred year's teaching experience in the field of mining and mineral processing. Graduates from AGH UST in the field of mineral processing are aware of the supply and availability challenges regarding to a wide range of raw materials (coal, metallic and non-ferrous metals ores, aggregates, chemical minerals etc.) and derived products, understand the societal function of raw materials and the need for a value chain approach to ensure the sustainable industrial utilization of resources. Mineral processing engineers during their studies have also chance to acquire entrepreneurial and innovation skills, useful in expanding the existing markets and in creating new ones. Educational activities are therefore closely related to societal needs in general and industrial needs in particular. In general, the graduate gains complete training in the problems associated with physical, physicochemical and chemical separation of the individual components of the raw material of fossil or mineral waste in order to obtain the concentrates for further processing technologies. Techniques and technologies of beneficiation are among others the subject of the study. Silesian University of Technology offers curricula "Mineral Processing and Management".

It is worth noticing that AGH UST is the only Polish University that also offers Master studies in the field of Mining Engineering in English language. This makes the AGH UST the only Polish University in the field of mining and mineral processing, that is prepared for serving the complete educa- tion of foreign students within full curriculum of MSc studies. It also opens opportunities for Polish graduates in terms of their mobility and international trainships. The graduates gain knowledge in the field of mining, including various methods of raw materials extraction, together with technology of their processing and waste treatment.

Several other universities offer curricula in Polish language in the field of mining, when selected issues of mineral processing are also delivered. These graduates are not a fully mineral processing engineers, but rather a mining engineers, but they are taught of some aspects related to mineral processing. Following universities should be mentioned: AGH University of Science and Technology, Gdańsk University of Technology, Łódź University of Technology, Silesian University of Technology and Wroclaw University of Technology. AGH UST offers two types of studies with elements of mineral processing: the one is run on Faculty of Mining and Geoengineering, and the other can be found on the Faculty of Mechanical Engineering \& Robotics, and the mineral processing issues are delivered from the scope of mining and mineral processing machinery and equipment.

Most of scientific staff related to mineral processing is located in AGH UST. More than ten full and associate professors work in the Department of Environmental Engineering and Mineral Processing at AGH UST. The other universities engage few professors in mineral processing, each. However, if we expand the research field to mining area, the number of professors is higher: only AGH UST engages around 40 professors, while in each of the other Universities there are between ten and fifteen to twenty professors. In general, the scientific staff engaged into higher education reach 150-200 people. About $80 \%$ of researchers and educators in the field of mineral processing are located in Cracow area.

The second activity in the field of mineral processing in Poland is related with various research institutes. Scientific workers of these institutes, especially professors, supplement educational activities served by universities, within the pro- 


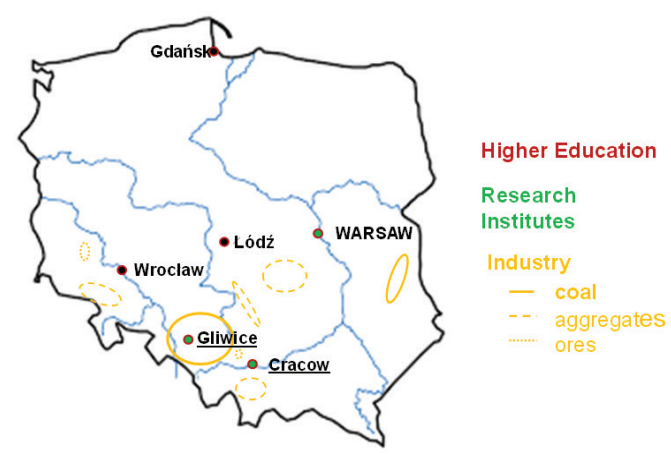

Fig. 1. Mineral processing institution in Poland along with selected industries

Rys. 1. Główne instytucje naukowe badawcze oraz ośrodki przemysłowe w Polsce związane z przeróbką surowców

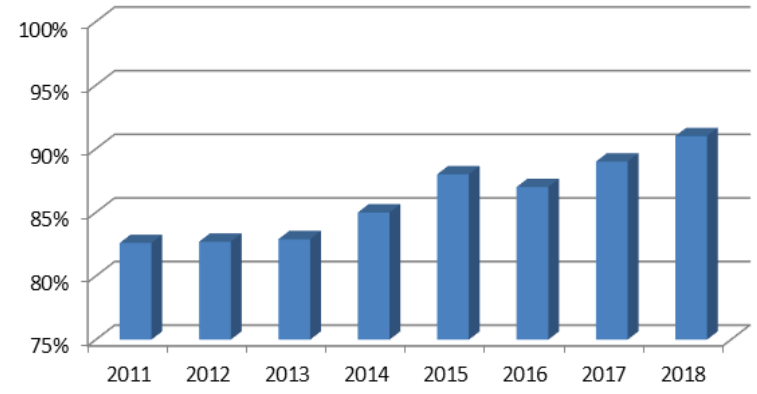

Fig. 2. Empolyment rate among graduates

Rys. 2. Odsetek zatrudnionych absolwentów

cess of junior researcher's scientific development (reviewers, tutors etc.). The institutes also collaborate with universities within the scope of professional practices, scholarships and industrial trainings. Following institutes should be listed: Central Mining Institute (GIG) located in Katowice, Mineral and Energy Economy and Research Institute of Polish Academy of Science (Krakow), Institute of Mechanised Construction and Rock Mining (Warsaw), Institute of Non Ferrous Metals (Gliwice), CUPRUM (Wrocław), The Institute of Ceramics and Building Materials (Opole, Warsaw, Krakow), Institute of Chemical Processing of Coal (Zabrze), KOMAG, many minor institutes engaged in research in aggregate sector, etc. It is hard to estimate the exact number of scientists engaged in all mining and mineral processing institutes, but we might say about at least 200 people.

The third vertex in a triangle Education-Research-Business constitutes the industrial sector. Mining and mineral processing industry covers copper (KGHM and related companies), coal (mining and processing plants located in Silesia region, and in eastern part of Poland), zinc and lead processing (near Cracow), aggregates sector, representing by many SME and large plants and some other minor types of raw materials. The major role plays KGHM, one of the world leaders in copper and silver production. It processes 30 million tons of ore annually. An outline of the above issues (selected) is shown in Figure 1.

\section{Curricula}

Educational programmes related to mineral processing in Poland should be divide into two main groups. The first group includes curricula strictly related to mineral processing
(Mineral Processing Curriculum). Graduates of these studies gain a comprehensive knowledge from mineral processing area and, as a result, become mineral processing engineers. The second category (Mining Curriculum) covers programmes in the field of mining, geoengineering and environmental engineering, which includes selected issues related to mineral processing.

The graduate of mineral processing curriculum in Polish conditions has a deepen knowledge of techniques and technologies of various beneficiation methods (gravitational, flotation, magnetic, electrostatic, chemical). This graduate is educated in the field of preparatory operations as well as supplementary ones, applied into processing technology, in particular comminution and classification processes, dewatering operations, various methods utilizing gravity, centrifugal, vacuum and pressure forces. Environmental protection issues and problems related to water management and waste utilization in accordance with the principle of sustainable raw materials management and utilization are of a key significance during the studies. Graduate is also well prepared for the material sampling and their qualitative and quantitative analysis. The other aspects include the operation of processing machinery and equipment, organization, management and economics, process automation, control and optimization, together with practical knowledge of raw materials deposits (geology, geochemistry, mineralogy and petrography).

The graduates from mining curriculum, who also have gained some knowledge in the field of mineral processing, have an in-depth knowledge in the field of mining, geology, environmental engineering, supported by chosen aspects of mineral processing. These aspects include: mineral processing 


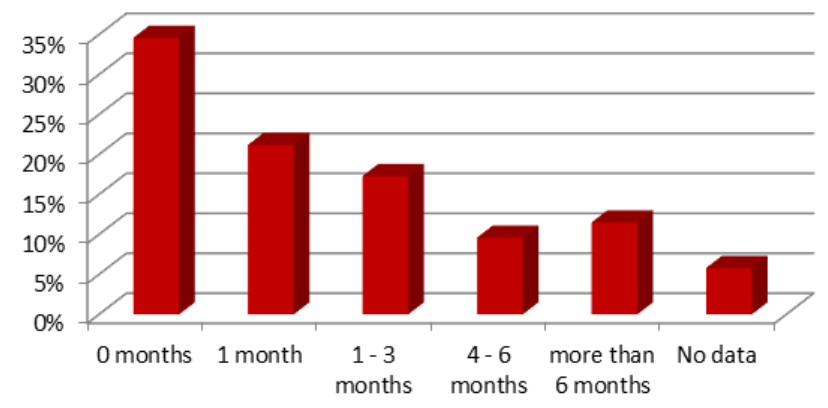

Fig. 3. The duration of looking for a job among graduates Rys. 3. Czas poszukiwania pracy przez absolwentów

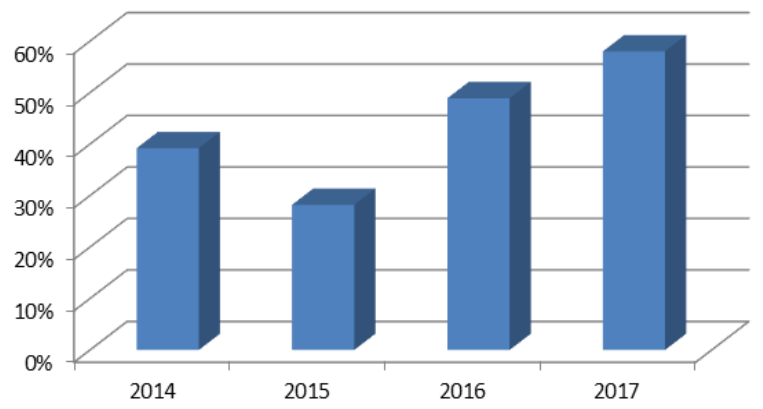

Fig. 4. Percentage of undergraduates with a job Rys. 4. Odsetek pracujących wśród studentów

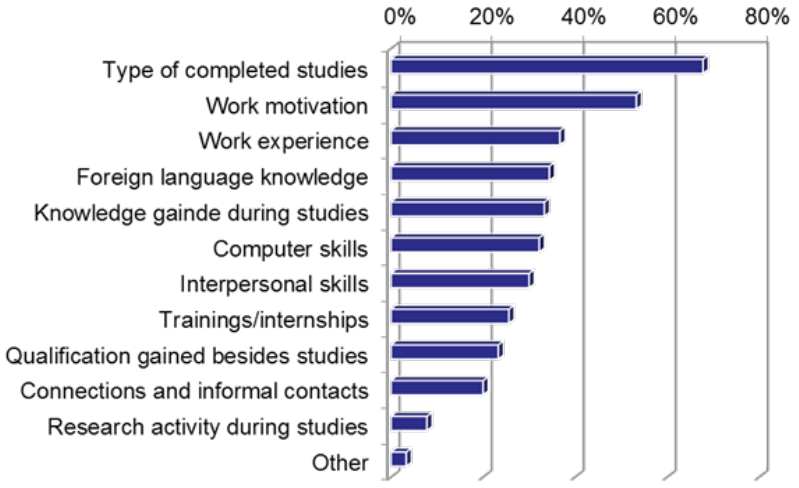

Fig. 5. Significant factors in job hiring

Rys. 5. Kluczowe czynniki decydujące o zatrudnieniu

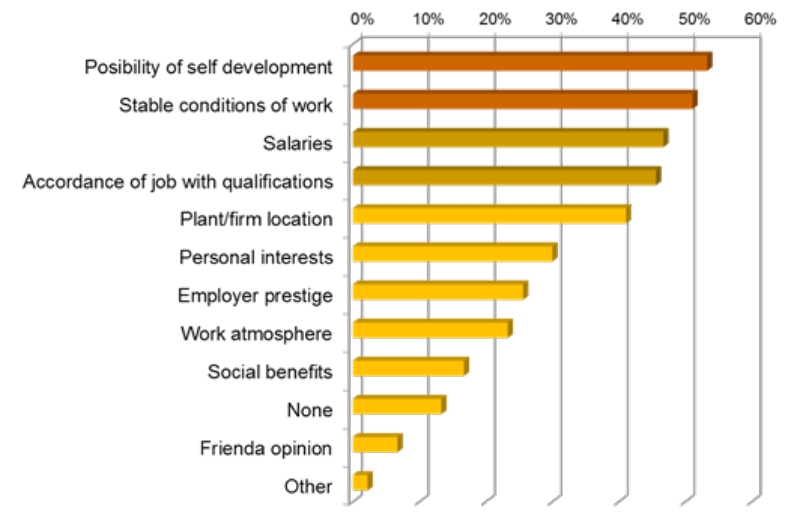

Fig. 6. Priorities in choosing a potential employer

Rys. 6. Kryteria odnośnie wyboru potencjalnego pracodawcy 


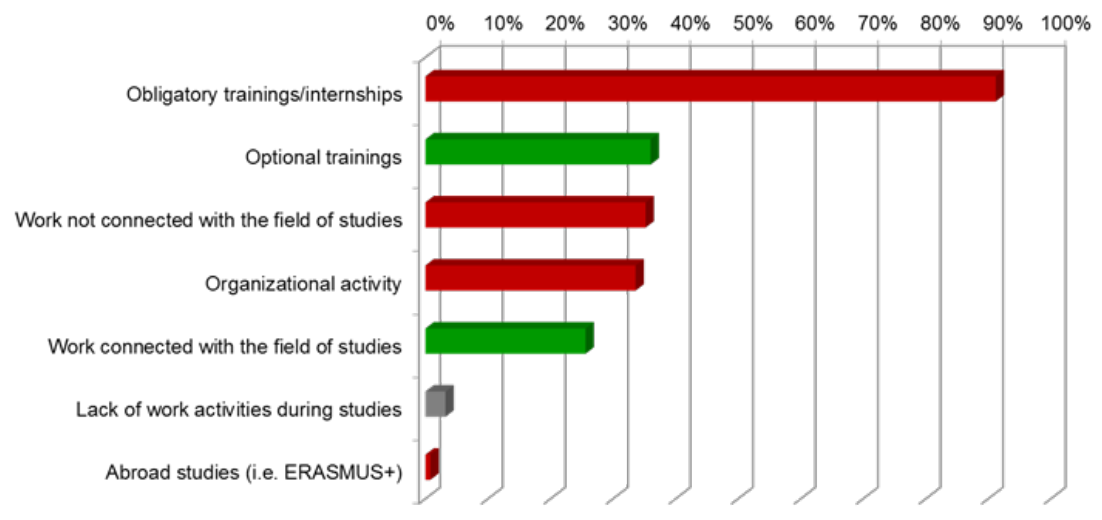

Fig. 7. Main activities during studies

Rys. 7. Główne aktywności wśród studentów podczas studiów

equipment, chosen methods of raw materials beneficiation, or selected operations in technological circuits of raw materials processing. The above issues may apply exclusively to selected raw materials (either coal or ores, or aggregates).

Teaching programmes in the field of mineral processing will be described on the example of curriculum applied at AGH UST. As it was mentioned the above, this university is a primary one in the field of higher education in Poland. However, the respective programme at Silesian University of Technology is similar. Mineral processing curriculum at AGH includes a number of various teaching modules that can be grouped into following categories:

- Base modules, that include Statistics, Contemporary Physics, Environmental Management and other similar subjects, which give the student an overall awareness of common laws of phenomena related to the field of study. Base modules cover 84 teaching hours.

- Technical modules, connected with mineral processing technology, methods of beneficiation, mineral resources economy, waste management, automation and process control, environmental and social issues. This group of subjects give the student the view of overall and specific engineering problems in the field of mining and mineral processing. The entire group covers 16 modules with nearly 400 teaching hours plus 170 hours of laboratory.

- Humanistic modules (managerial psychology, negotiations) help to develop non-engineering skills, as well as increase selected soft skills of future engineers, like interpersonal abilities, team working and public presentation skills.

- English module that, apart from obligatory English language course (30 hours), include an elective course, taught in English language (30 hours).

- Industrial practice, which is realized in mining and mineral processing plants, and takes 4 weeks.

AGH UST, as the only university in Poland, also offers regular $\mathrm{PhD}$ studies in the field of mineral processing. These four-year studies are offered on Faculty of Mining and Geoengineering, and are held in Polish language. Studies in English are also possible, but that requires initial arrangements, because the programme is tailored for particular requirements of $\mathrm{PhD}$ candidate. Four main fields of studies are available: Mining and Geology, Environmental Engineering, Manage- ment and Production Engineering, Civil Engineering. Each of the above fields is focused on different engineering issues, and doctorate in mineral processing is possible to complete in the field Mining and Geology, and Environmental Engineering. The teaching modules within these studies are connected with the selected field of study, and include methodology of scientific research and emphasis on possibilities of raising of various types of funds for research. The doctoral dissertation is usually realized in cooperation with industry.

\section{Graduates - their future career and professional devel- opment}

Graduates are the professionals who meet no major difficulties in work market. The AGH Career Centre monitors future career of graduates, and the below figures were prepared on the basis of data from the center. High rate of employment among mining and mineral processing engineers is observed, which was well above $85 \%$ during last four years (Fig. 2).

Graduates are also able to find the job relatively quick. Nearly half of graduates need one month or even less to find a job, while only about 10 per cent of them look for a job more than six months (Fig. 3).

A large number of job offers in the field of mineral processing has its reflection in the rate of undergraduates with a job. Some percentage of future graduates have the job even before graduation (Fig. 4), and this number in 2017 was as even higher than $50 \%$.

As high as $67.3 \%$ of graduates claim, that their job is fully compatible with the profile of completed study. Further $9.6 \%$ thinks that the job is partially compatible, and $19.2 \%$ consider it as incompatible. The $3.8 \%$ of graduates have not given the answer.

Figure 5 shows main factors regarded as significant in job hiring, while Figure 6 presents which priorities graduates take into consideration while choosing a potential employer. Type of completed studies and work motivation play the most significant role in employment. Graduates consider the possibility of self-development at work and stable work conditions as key priorities in making decision when choosing a potential employer.

The usefulness of knowledge gained during the studies is assessed as very high and high by $41.3 \%$. The next $55.2 \%$ graduates claim that the gained knowledge and qualifications 
are sufficient. Only $3.5 \%$ graduates considers their gained knowledge as low. Graduates also assess that studies have prepared (17.2\%) or partially prepared (69\%) them to the job. The remaining $13.8 \%$ have negative opinion within this issue. Figure 7 shows what types of activities graduates have taken up during their studies. The low mobility among students is a concern. On the other hand, a significant percentage of graduates would like to continue their professional development on post graduate/ $\mathrm{PhD}$ studies. Nearly $25 \%$ graduates want to enroll on postgraduate studies, while around $40 \%$ consider that possibility. What is more, about $8 \%$ is already during their post graduate studies.

\section{Feedback from the industry}

The other side of assessment of graduates are the opinions of employers. Some feedback from industry sector was collected and the most relevant opinions were presented the below. It is worth to note that employers are tend to assess their employees within two scopes: taking into account their gathered knowledge and practical skills and considering their personal skills. Knowledge of mineral processing engineers graduated from AGH UST is assessed well and very well, in general. They are also regarded as ambitious persons. On the other hand their foreign language knowledge is assessed as well or average, what can be of both the positive and negative meaning. Among the other negatives the following are mentioned:

- Poor practical utilization of the gained knowledge

- Unhealthy competition (too ambitious)

- Poor task concentration skills

- Poor communication skills, both in written and oral. In various opinions this feature might be connected with many digital gadgets utilized during daily routine of young peoples (smartphones, smartwatches, laptops etc.), what results in lower intensity of personal communication with contemporaries and colleagues.

Considering the fact the AGH is considered as the Polish leader in higher education in the field of mining and mineral processing, it is reasonable to assume that candidates from the other universities might be assigned with a bit higher number of the other negatives or positives.

As it was mentioned the above, the employers have separately assessed personal skills of graduates/employees. Among the main positives they considered the declared mobility of workers. It appears that if necessary, the employees are ready to move, even abroad. The other positive feature is very good knowledge of electronical technology and practical utilization of Internet. Several negatives were also mentioned: poor team working skills, too high demands at the very beginning of their professional career, poor self-organization, claiming attitude and lack of independence. At the same time industry people determined a kind of profile of perfect graduate. Such a person:

- Should be aware of general problems relating to raw materials availability and supply,

- Should understand societal/environmental function of raw materials (value chain approach, sustainable utilization of resources etc.),

- Should have a deepen knowledge, which is important but not critical,

- Should have professional skills (team work, report writing), analytical thinking, problem solving and data analysis, which are of very significant importance.

\section{Conclusions and final remarks}

The situation in mineral processing education in Poland is well, however some improvements are advisable. Many university teachers and industry representatives agree that main improving activities should aim at:

- Further development and management of educational programmes and activities related to raw materials,

- Formation of professionals who have a deep understanding of specific aspects related to mineral processing,

- Bringing together three aspects: business (large companies and SMEs), higher education institutions and research centers.

The above activities can be run locally and globally. Universities and research centers cooperate with the industry sector within this area. Educational programmes are being modified and adjusted to the changing conditions. Teaching staff is up to date the recent scientific achievements which are utilized in educational programmes. One of examples of solutions in global scale is a European initiative KIC Raw Materials. This international program aims at increasing the competitiveness of Europe in the field of raw material, through various educational activities. 


\section{Literatura - References}

1. AGH University of Science and Technology, CAREER CENTRE - Unit for monitoring of Graduates Professional Development - reports

\section{Programy edukacyjne z zakresu przeróbki surowców w Polsce}

Górnictwo i przeróbka surowców to znaczące kierunki badań w Polsce, głównie dzięki bogatym krajowym zasobom licznych surowców mineralnych. Kilka uczelni wyższych w Polsce prowadzi studia z zakresu przeróbki surowców. AGH w Krakowie to jedna z głównych uczelni oferujacych studia magisterskie $w$ dziedzinie przeróbki. Także na innych uczelniach studenci mogą zdobyć wykształcenie $z$ zakresu przeróbki. Oferowane programy edukacyjne obejmuja wszystkie kluczowe tematy związane z przeróbka surowców, we współpracy z przemysłem węglowym, miedziowym, cynkowo-ołowiowym, oraz kruszywowym. Artykuł także porusza kwestie zwiazane z kadra naukową w Polsce. Zaprezentowane zostały także możliwości rozwoju zawodowego dla absolwentów z uwzględnieniem głównych szans oraz zagrożeń.

Słowa kluczowe: przeróbka surowców, szkolnictwo wyższe, AGH 